\section{Responsive innovation}

Innovative manufacturing processes have developed instruments which have revolutionised canal preparation, such as nickel titanium (NiTi) rotary files, controlled memory (CM) files and, the latest generation,

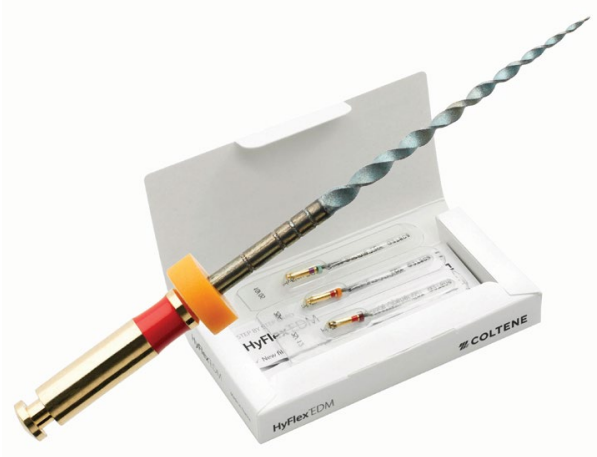

\section{See with extraordinary precision}

When it comes to diagnostic imaging, versatility and precision are key.

The CS 9600 CBCT scanner from

Carestream Dental is the ultimate imaging system for professionals who want to ensure high-quality diagnostics.

A versatile, 5-in-1 system that provides exceptional 2D and 3D imaging quality across a variety of modalities, the CS 9600 also has helpful features such as CS MAR. This optional module reduces the appearance of metal artifacts on scans for even greater image precision.

The system is scalable and offers 14 different fields of view, ensuring that it can be used in every instance from simple routine diagnostics to dental

those manufactured with electrical discharge machining (EDM).

COLTENE produces NiTi, CM NiTi and EDM files; its HyFlex EDM files have up to $700 \%$ more fracture resistance than other options and the sequence covers all bases, from everyday endodontics to complex cases.

The HyFlex range has evolved to meet the requirements of specialists and their patients; this is responsive, intelligent innovation.

COLTENE has the tools, equipment and materials to take your treatments to the next level.

Contact the team today.

For more on COLTENE, visit www.coltene. com, emailinfo.uk@coltene.com or call 0800 2545115.

implant planning, orthodontics and more.

Step into the future of imaging with the CS 9600 today. For more information, contact Carestream Dental on 0800169 9692 or visit www.carestreamdental.co.uk.

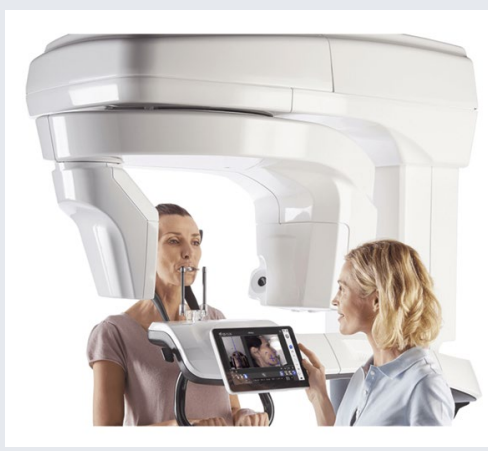

\title{
Soft tissue around dental implants course
}

From BPI Dental Education \& Training

Birmingham, the Soft Tissue Around Dental Implants course is selling out fast.

Book your place now for remaining 2021 dates:

- 24-25 September 2021

- 22-23 October 2021

- 26-27 November 2021.

The course provides hands-on tuition from Dr Boota Singh Ubhi - a Specialist Periodontist with more than 25 years' experience with dental implants. Training enables delegates to diagnose potential soft tissue complications prior to implant treatment so they can be minimised or avoided completely. Various plastic periodontal surgical techniques are also taught to optimise aesthetics and longevity of outcomes.

Making this course unique, delegates are provided with an iPad for the duration of training to facilitate an exceptional mentorship and support.

With space on only three courses left for this year, book today to avoid disappointment. Visit https:// bpieducation.co.uk/dental-courses/. issue-around-dental-implants/.

\section{A safety net for the future}

With so much uncertainty in the world right now, it pays to ensure that you have proper protections in place for both you and your practice.

The team at insurance4dentists are there to help you navigate the labyrinth of available insurance policies. With years of experience and multiple awards under their belt, the team offers impartial, easy to understand and practical advice for dental professionals. They are there to ensure that you take out insurance policies that will pay out and provide protection when you need them most.

From income protection to home insurance, the team offers guidance covering every aspect of all insurance policies, meaning that you always end up with safeguards that won't let you down.

For more information call 0845 3455060 or 0754 DENTIST. Email info@4dentistsgroup.com or visit www.4dentistsgroup.com.

\section{Join the debate}

Modern dentistry is all about finding innovative ways of solving new clinical challenges. The Association of Dental Implantology (ADI) provides the opportunity for clinicians and their teams to discuss new ideas and assess emerging treatments with the ADI Team Congress 2022.

The event will feature a unique mixture of lectures and workshops, with sessions tailored to each member of the dental team. Entitled 'The Great Debate: Current Dilemmas in Dental Implantology', the educational programme will see industry-leading and internationally renowned speakers share their insights and opinions on key topics.

Join the debate - don't miss the ADI Team Congress which will be held at Manchester Central on 26-28 May 2022. ADI members will be able to attend the ADI Team Congress for discounted rates. Join today: www.adi. org.uk/congress 22 . 